\title{
International Instrument on Permitted Uses in Copyright Law: An Introduction
}

\author{
Reto M. Hilty $\cdot$ Valentina Moscon
}

Published online: 20 January 2021

(C) The Author(s) 2021

In copyright law, the matter of permitted uses is as important as it is controversial at both the national and the international levels. The latest of many debated examples concerns South Africa. In June 2020, the President of the African National Congress, Cyril Ramaphosa, returned the Copyright Amendment Bill, ${ }^{1}$ which had been approved at the end of 2018, to Parliament. The Bill included fair use provisions and other exceptions and limitations to copyright. ${ }^{2}$ President Ramaphosa claimed the proposed copyright-permitted uses violated South Africa's international obligations under the Berne Convention, which are partly also included and expanded in the WTO's TRIPS Agreement and WIPO Copyright Treaty. In particular, the Bill was deemed in conflict with the three-step test. At the international level, much attention has been paid to the South African reform. Both

\footnotetext{
1 Republic of South Africa, Copyright Amendment Bill B 13B-2017, https://www.gov.za/sites/default/ files/gcis_document/201811/copyright-amendment-bill-b13b-2017.pdf.

2 Khusela Diko, "Spokesperson to the President, President Cyril Ramaphosa refers Copyright and Performers' Protection Amendment Bills to Parliament", 23 June 2020, https:/www.gov.za/speeches/ president-cyril-ramaphosa\%C2\%A0refers-copyright-and-performers'-protection-amendment-bills. See also Chijioke Okorie, "Long walk to copyright reform: South Africa's Copyright Amendment Bill is back to the National Assembly", Tuesday, 23 June 2020, http://ipkitten.blogspot.com/2020/06/long-walk-tocopyright-reform-south.html.
}

R. M. Hilty

Prof. Dr. Dr. h.c.; Director at the Max Planck Institute for Innovation and Competition; Professor, Universities of Zurich and Munich (LMU), Munich, Germany

e-mail: hilty@ip.mpg.de

V. Moscon ( $\bowtie)$

Dr.; Senior Research Fellow at the Max Planck Institute for Innovation and Competition, Munich, Germany

e-mail: valentina.moscon@ip.mpg.de 
the United States ${ }^{3}$ and the European Union ${ }^{4}$ pressured South Africa to defer this legislation. The request was leveraged based on trade agreements ${ }^{5}$ and through the possibility of investment withdrawals. ${ }^{6}$

This international pressure, which not only South Africa but a number of other states has had to bow to, triggered an international research project coordinated by the Max Planck Institute for Innovation and Competition in Munich (MPI) to develop an "International Instrument on Permitted Uses in Copyright Law" (hereinafter "the Instrument"). The purpose of the Instrument is to provide states that wish to resist such pressure with an independent set of mandatory rules enabling them to coordinate their interests and jointly defend a minimum level of freedom related to certain acts of use.

The Project was launched in 2011, during the same period in which the planned Anti-Counterfeiting Trade Agreement (ACTA) prompted heated discussions and public demonstrations. The initiative originated with some members of the expert group working on the "Declaration for a Balanced Interpretation of the Three-Step Test in Copyright Law", which was concluded in 2008 (hereinafter "the Declaration"). ${ }^{7}$ The Declaration offers a more flexible interpretation of the threestep test in copyright law in order to take account of legitimate user interests. The Declaration received broad international recognition, with numerous leading scholars around the world supporting it. Nevertheless, its impact on politics, jurisprudence and legislation has so far been limited. Countries with strong copyright industries in particular do not seem to care much about the concerns raised by the academic community. Quite the opposite, they continue their efforts to establish ever higher and more rigid standards of IP protection without properly taking account of a balance of interests. In practice, these attempts have proven successful through their use of new strategies. The focus no longer lies on an international consensus within transparent institutions and bodies. States that wish to impose strong protection to preserve their own industrial interests have learned from the failure of ACTA; ${ }^{8}$ today, they rather rely on bi-lateral or regional freetrade agreements. ${ }^{9}$

\footnotetext{
${ }^{3}$ United States Trade Representative, 2020 National Trade Estimate Report on Foreign Trade Barriers, p. 445 et seq., https://ustr.gov/sites/default/files/2020_National_Trade_Estimate_Report.pdf.

${ }^{4}$ The European Commission sent a letter to the South African government, https://eeas.europa.eu/sites/ eeas/files/20200320_copyright_regime.pdf.

5 The United States Trade Representative announced in 2019 a review of South Africa's trade deal with the United States. This news was reported by the African News Agency on 17 January 2020, https://www. iol.co.za/personal-finance/copyright-law-threatens-sas-trade-with-us-40727170.

${ }^{6}$ Laura Kayali, 28 June 2020, "How the U.S. and European Union pressured South Africa to delay copyright reform", https://www.politico.com/news/2020/06/28/copyright-reform-south-africa-344101.

${ }^{7}$ www.ip.mpg.de/en/research/research-news/declaration-three-step-test.html; see also Christophe Geiger et al., "Declaration on a Balanced Interpretation of the 'Three-Step Test' in Copyright Law", 39 IIC 707-713 (2008).

${ }^{8}$ Matthews, D., Žikovská, P. "The Rise and Fall of the Anti-Counterfeiting Trade Agreement (ACTA): Lessons for the European Union”, 44 IIC 626-655 (2013), https://doi.org/10.1007/s40319-013-0081-y.

${ }^{9}$ Regional Trade Agreements Database, https://rtais.wto.org/UI/PublicMaintainRTAHome.aspx. With particular regard to copyright law, see Marketa Trimble, "TRIPS in the Field of Copyright" (5 April 2020).
} 
This international development in IP law in general and copyright law in particular, however, jeopardises the sovereignty of a number of economically dependent countries and their freedom to design their copyright legislation to align with domestic cultural, social and economic needs. This increasingly threatens the equal consideration of all interests involved, highlighted in Art. 7 of the TRIPS Agreement and the preamble of the WIPO Copyright Treaty as "the need to maintain a balance between the rights of authors and the larger public interest, particularly education, research and access to information". Affected are not only developing countries, but also users in developed nations. At the same time, it has become increasingly clear that the Declaration, which shows in a rather abstract way what flexibility the international legal regime in principle offers, is not sufficient. What has been missing so far are concrete rules to guide national legislatures in achieving the necessary balance of interests.

The Instrument was conceived to remedy this deficit. The MPI initiated the project by inviting distinguished and outstanding researchers from all over the world to a kick-off meeting in Munich. This meeting was attended by Denis Borges Barbosa (Brazil), Michael Carroll (United States), Carlos Correa (Argentina), Thomas Dreier (Germany), Séverine Dusollier (France), Christophe Geiger (France), Jonathan Griffiths (United Kingdom), Henning Grosse Ruse-Khan (United Kingdom), Reto M. Hilty (Germany), Kaya Köklü (Germany), Annette Kur (Germany), Xiuqin Lin (China), Ryszard Markiewicz (Poland), Sylvie Nérisson (France), Gül Okutan Nilsson (Turkey), Alexander Peukert (Germany), Jerome Reichman (United States), Jan Rosén (Sweden), Martin Senftleben (the Netherlands), and Raquel Xalabarder (Spain). On that occasion, a structure for a possible legislative text was developed and working groups were formed. These groups in a first step drafted the individual provisions, which subsequently were intensively discussed and developed in various meetings. At a later stage, the finalised legislative text was supplemented with explanatory notes. After additional rounds of discussion and improvements the whole package was finally adopted as a common basis for the proposed International Instrument. The legislative text is available in this issue ${ }^{10}$ the explanatory notes have been published online. ${ }^{11}$

The Instrument contains a core of minimum permitted uses of works that is binding for potential member states in the sense that they would be obliged to implement this core of permitted uses in their national legislations. With this "minimum permitted uses approach", the Instrument aims at counterbalancing the traditional "minimum protection approach" of international copyright legislation. The obligation constitutes a ceiling beyond which copyright protection may not prohibit the use of works. With this approach, the Instrument aims to place a lever in the hand of states to address the political pressure in international negotiations of bilateral or regional agreements in particular. Once in place, such an Instrument might, among other things, facilitate cooperation amongst countries and help them to assert their common interests in international negotiations on an equal footing

\footnotetext{
${ }^{10}$ For the text of the Instrument see this issue of IIC at https://doi.org/10.1007/s40319-020-00999-8.

11 The explanatory notes form a part of the Instrument and are available at https://www.ip.mpg.de/ fileadmin/ipmpg/content/forschung/International_Instrument_Explanatory_Note_2020-12-18.pdf.
} 
with groups of countries invoking Art. 1(1) TRIPS to impose higher standards of protection in international negotiations. At the same time, by ensuring minimum permitted uses, implementing the Instrument in binding international legislation might foster a certain harmonisation with regard to the limits of copyright protection.

While setting forth mandatory minimum standards, the approach of the Instrument should not under any circumstances be interpreted as binding the contracting parties to its core of permitted uses. Any contracting party remains free to go beyond this core and permit further uses, should its domestic needs require such national legislation. Contracting parties are also free to determine the appropriate method of implementing the permissions provided by the Instrument explicitly enumerating such permitted uses, creating general clauses or basing them on a fair use or fair dealing legislation are all matters of the national legal systems.

The Instrument is composed of three parts: A. Permitted uses; B. General principles of implementation; C. Competition; Abuse.

In Part A five groups of permitted uses are specified: I. Freedom of expression and information; II. Social, political and cultural objectives; III. Use of software; IV. Uses with minimal significance; and V. Free circulation. The permitted uses listed in Part A include those codified in international provisions (such as Art. 10(2) Berne Convention or the Marrakesh VIP Treaty) as well as in national rules in this area. The conceptual structure of the rules on permitted uses in the Instrument is similar to the one characterising the provisions of the European Copyright Code, that is the result of the Wittem Project (namely Chapter 5: Limitations). Each rule establishes initially the objective pursued by the provision (e.g. "Freedom of expression and information"). The permitted uses listed by way of example in the second paragraph of the provision are precisely meant to serve the values enunciated in the first paragraph. Part B defines general principles aimed at guiding contracting parties in the implementation of permitted uses in their national legal orders. Part $\mathrm{C}$ deals with competition law as an external limit to copyright. This part is based on the modern understanding that competition law and copyright law are not antagonistic but rather complementary fields of law, pursuing the objective of increasing the market offering of creative works.

In the recent past, an impressive number of representatives from states that feel under pressure in international negotiations have called for such a set of rules. It is to be hoped that the ball will now be taken up by these countries in particular. However, even if no legislative implementation should take place in the near future, the Instrument will offer an academic milestone and an additional opportunity to push forward the discussion on a future-oriented copyright law.

Open Access This article is licensed under a Creative Commons Attribution 4.0 International License, which permits use, sharing, adaptation, distribution and reproduction in any medium or format, as long as you give appropriate credit to the original author(s) and the source, provide a link to the Creative Commons licence, and indicate if changes were made. The images or other third party material in this article are included in the article's Creative Commons licence, unless indicated otherwise in a credit line to the material. If material is not included in the article's Creative Commons licence and your intended use is not permitted by statutory regulation or exceeds the permitted use, you will need to obtain permission directly from the copyright holder. To view a copy of this licence, visit http:// creativecommons.org/licenses/by/4.0/. 
Funding Open Access funding enabled and organized by Projekt DEAL.

Publisher's Note Springer Nature remains neutral with regard to jurisdictional claims in published maps and institutional affiliations. 